\title{
Influential Factors of Network Changes: Dynamic Network Ties and Sustainable Startup Embeddedness
}

\author{
Julia Keidel $^{1}$, Peter M. Bican ${ }^{1, *(1)}$ and Frederik J. Riar ${ }^{2}$ (D) \\ 1 Chair of Technology Management, University of Erlangen-Nuremberg, 90762 Fürth, Germany; \\ keidel.j.julia@gmail.com \\ 2 Institute of Management, Karlsruhe Institute of Technology, 76133 Karlsruhe, Germany; frederik.riar@kit.edu \\ * Correspondence: peter.bican@fau.de
}

check for

updates

Citation: Keidel, J.; Bican, P.M.; Riar, F.J. Influential Factors of Network Changes: Dynamic Network Ties and Sustainable Startup Embeddedness. Sustainability 2021, 13, 6184. https:// doi.org/10.3390/su13116184

Academic Editor: Adam Jabłoński

Received: 21 April 2021

Accepted: 19 May 2021

Published: 31 May 2021

Publisher's Note: MDPI stays neutral with regard to jurisdictional claims in published maps and institutional affiliations.

Copyright: (c) 2021 by the authors. Licensee MDPI, Basel, Switzerland. This article is an open access article distributed under the terms and conditions of the Creative Commons Attribution (CC BY) license (https:/ / creativecommons.org/licenses/by/ $4.0 /)$.

\begin{abstract}
This research investigated influential factors on changes in networks of startups through a qualitative exploratory case study approach. Based on interviews with founders in Germany and selected stakeholders in entrepreneurial networks combined with a network mapping approach, we developed a framework of influential factors on network changes. In essence, this framework categorizes factors into sustainable resource acquisition, knowledge and skill acquisition, interpersonal factors, and interorganizational factors. Overall, our research contributes to a better understanding of factors that impact network changes by providing a construct with potential for theoretical standardization. In addition, this research offers important managerial implications.
\end{abstract}

Keywords: startup; entrepreneurship; entrepreneurial firm; network; network changes; influential factors; ties; relationships

\section{Introduction}

Networks have received increasing attention as contributors to sustainable entrepreneurial success since they benefit entrepreneurial capacity in terms of finances, technologies, marketing, and social aspects [1]. Since Aldrich and Zimmer [2], the observation of networks has developed from static approaches to dynamic ones because scholars considered that this matches the characteristics of startups as their needs for various resources, like technological capability or investments [3], are constantly changing [3,4]. Besides these resources, which served as a factor for network changes [3,5-9], additional factors have only been researched in a very fragmented manner and through varying network perspectives. For instance, Kocka et al. [10] elaborated influential factors on changes of the overall network of one industry. Additionally, the factors of network change have also been investigated by observing the egocentric network of one firm [1], since changes within this network also affected changes in the overall network of an industry [10]. Furthermore, networks were investigated on different levels defined as interpersonal, interunit, or interorganizational networks [11]. Even though these three levels could be defined separately, it has been difficult in entrepreneurial research to examine them independently [12]. This is because, as Johannisson and Mønsted [13] noted, entrepreneurs who acted on the interorganizational level as representatives of their startup still influenced all decisions and actions of the startup by their personal intention and conviction. In addition, the categorization of the identified factors consisted of different constructions. Soetanto et al. [3], for example, used a classification according to internal and external factors, while Larson [8] analyzed the factors according to the different stages of development of the ties.

It is evident that it has been challenging to merge all the existing methodologies into one comprehensive framework. To address these shortcomings in the current literature, we study what factors influence network changes in entrepreneurial firms at the interpersonal and interorganizational level. To fully exploit the initially mentioned positive impact of entrepreneurial networks on sustainable entrepreneurial success as, for example, was 
investigated by Brüderl and Preisendörfer [14], it is important to provide a comprehensive overview of factors which impact entrepreneurial ties and hence the entrepreneurial network as a whole [15].

This paper provided a comprehensive framework for the categorization of influential factors, thereby addressing the applicability of the factors already elaborated in the literature and investigating new influential factors. This was accomplished through a qualitative exploratory case study approach. In the following section, the theoretical background of networks and their dynamic nature is introduced. Afterwards, the methodological approach of the paper is presented, including data collection and analysis. Based on the data analysis, the findings are presented and discussed afterwards. Finally, theoretical as well as practical implications are demonstrated and suggestions for further research are derived.

\section{Theory}

\subsection{Definitions}

Over the last decades, two distinct research streams developed within the research of entrepreneurial networks $[16,17]$. One stream investigated networks as an independent variable influencing the performance of startups [14,18-26]. The other, lessresearched stream considered networks as a dependent variable, i.e., why and how networks evolve [3,6,8,11,15,27-29].

In general, Brass et al. [11] p. 795 defined networks "as a set of nodes and the set of ties representing some relationship, or lack of relationship, between the nodes". Although this definition made clear that a tie always consists of at least two nodes, in the past researchers as, for instance, Birley [22], Martin et al. [6], or Soetanto et al. [3,30] considered only one side of the tie. Turning to the main components of networks, Hoang and Antoncic [16] divided them into three main terms: network content, network structure, and network governance. The main purpose of networks was to exchange resources, including information, ideas, advice, emotional support, and knowledge [14,22]. In addition, ties could be especially helpful for startups to build their own reputation [31]. To access those different kinds of content, it was important to take position within the network. This position within the network was characterized by the pattern of direct and indirect ties to certain actors, which was defined as network structure. This second component could be measured both by means of network size, which was defined as the number of direct ties of the investigation unit, and network density, which was defined as the number of interconnections between the network partners [16]. In terms of the network governance, trust played a critical role. This was because trust in the mutual fulfillment of expectations could replace legal contracts and, thus, create cost advantages for both partners [16]. This aspect could in turn be associated with the network content component, as failed network governance could lead to reputation loss [32]. Trust could also influence the depth of cooperation since partners who trusted each other were more likely to share strategically relevant assets [23].

\subsection{Patterns of Network Change}

To identify changes within networks, it is necessary to clarify different change patterns. They can be divided into the structural and the relational dimensions [3]. These dimensions are closely linked to the main components of networks explained above. First, structural network change can be defined by tie creation and tie deletion since the structure of networks is measured by the network size [10]. Second, based on network governance, changes within the relational dimension are measured by the strength of a tie, which Granovetter [33] p. 1361 characterized as "the amount of time, the emotional intensity, the intimacy (mutual confiding), and the reciprocal services". Strong ties provide mutual trust, defined as a part of network governance, and, thus, access to more confident information [34]. On the contrary, weak ties provide more diverse information because these ties link partners that would otherwise be disconnected through bridging holes [33,34]. In 
sum, we build on these change patterns, that are, tie creation, tie deletion, and changes in the strength of the tie $[11,35,36]$.

\subsection{Process Theories}

The ability to observe these patterns of network changes comes with understanding of change processes. Thus, different process constructs defined as life-cycle, teleological, evolutionary, and dialectic process theories investigated by van de Ven and Poole [37] came into use within entrepreneurial research. The approach applied by most authors, for instance Hite and Hesterly [38] or Lechner and Dowling [21], was the life-cycle process theory. This theory divides the business cycle of firms into different phases such as the startup birth or growth and therefore benefited the analysis of process data in a structured way.

\subsection{Factors Identified in the Literature}

Turning to the already-identified influential factors (see Appendix A) on network changes, some authors chose networks of firms in general as the unit of investigation $[5,7,11]$, while others specifically investigated networks of startups $[3,6,8,9]$. The first factor that was widely known both in entrepreneurial and overall organizational literature was the procurement of critical resources to survive as a firm [3,5-9,39].

Regarding factors investigated within the overall organizational research, Galaskiewicz [5] summarized other factors in his study that affected tie creation of a firm and, consequently, changes in networks. One factor that drives firms to collaborate with others is uncertainty [5]. Decisions must be made based on fragmentary information about the environment. Therefore, firms rely on network partners to achieve a better information flow and, thus, to reduce the uncertainty they faced in the environment [5]. The next factor determined by Galaskiewicz [5] was the improvement of legitimacy. Firms must assert themselves on the market and demonstrate compliance with various standards and regulations. This pressure motivates them to cooperate with other recognized firms to improve their legitimacy [5]. Brass et al. [11] argued that firms with network experience tended to expand their network with new and diverse partners. Thus, learning is another factor that can influence the approach of networking and therefore the networks themselves [11,40]. Ahuja et al. [7] also contributed with additional factors influencing tie creation. They stated that, on the one hand, added value, defined within their paper as agency, was important to develop a new tie [7]. On the other hand, convenience in terms of geographical proximity or identity-based similarity was an influential factor [7].

In the field of entrepreneurial research, Soetanto et al. [3] made a significant contribution to influential factors on networks of startups. They elaborated several factors, which they divided into internal and external obstacles [3]. Internal obstacles were defined as the lack of marketing knowledge and sales skills, managerial and financial skills, technological capability, access to research and development facilities, and investments [3]. External obstacles were defined as the lack of knowledge about customer or market demand, dealing with technological change, with the competition, and industrial structure, with regulations, standardization and bureaucracy, and with the lack of market demand [3]. In summary, there were a lack of resources, knowledge, and skills in areas critical to success. Larsons' [8] paper also contributed to network research in the field of entrepreneurship. She examined three phases of forming new ties, "preconditions, conditions to build the exchange structures, and the final phase of integration and control" [8] p. 98. Factors that positively influence the precondition phase are prior relationships and personal reputations [8]. This suggests that the social context can form a solid basis for economic relations, as trust is already present on a personal level [8]. Another factor enhancing tie creation is the firms' reputation, since ties are more likely to be established with companies that offer high quality products [8]. In terms of conditions to build the exchange structures, trust and the development of reciprocity enhance the tie creation and strengthening process [8]. Trust grows with the successful iteration of action and reaction, defined as the development of 
reciprocity [8]. Another influential factor for tie creation is mutual economic advantage, where Larson [8] found that it was not the economic value, per se, but growth that was important. Within the last phase of tie formation, it is important that operational and strategic integration take place to strengthen the tie [8]. Operational integration enhances the communication between the two firms [8], whereas strategical integration increases the interdependence of the firms in terms of joint projects or processes [8]. Martin et al. [6] also identified trust as an influential factor for tie creation. In line with Soetanto et al. [3], they also argued that obstacles influenced network changes [6]. Furthermore, they took characteristics of the founder into consideration by identifying the educational level and the level of intrinsic motivation of the founder as influencing factors [6]. Thus, educated and intrinsically motivated founders are more likely to form ties [6]. Another new factor that Martin et al. [6] elaborated in terms of the founders' characteristics, in line with Danso et al. (2016), was that risk-taking propensity was positively related to the creation of new ties since new ties always provide some sort of risk. The next factor that enhances tie creation is joint innovation projects, which can enhance the technological capability of a startup [6]. The last factor that was identified by Drummond et al. [9] was social media, which serves as a new way to create ties within the network of startups.

\section{Methodology}

\subsection{Qualitative Exploratory Single Case Study Approach}

Based on a qualitative research approach, we aimed to develop a better understanding of factors that influence network changes in entrepreneurial firms at the interpersonal and interorganizational level. Qualitative work is suitable to gain deeper insights providing first conceptualizations to stimulate further theory constellations [13,16,41,42]. Furthermore, especially in the field of network research, many authors such as Hite [15], Jack et al. [1], and Steier and Greenwood [27] have also applied the case study approach and, regarding the research question, Yin [43] proposed that "what" questions, which are of an exploratory nature, could be answered with an exploratory case study approach. Specifically, this paper applied a single-case approach. On the one hand, the individual ties within the interpersonal and interorganizational subunits of the startup can be investigated as an embedded single-case study [43]. On the other hand, the selected case, which is described below, is a common case, which made it possible to capture the everyday life and dynamic actions of startups [43].

To conduct this exploratory single-case study, the startup movelab was chosen as the research unit. Movelab has developed a specific line of nutritional supplements primarily for tennis players and, thus, they sell their products currently only within the tennis industry, which Hoang and Antoncic [16] determined as favorable for valid study results. Movelab launched their product line in Germany in 2017. All of their products are also produced in Germany, which was an important strategical aspect for them. To better connect their customers, products are sold under the brand name 'dropshot'. In addition, the strategy of movelab is to grow with little capital and without external investment. To extend their brand's reach, they wanted to penetrate the national market in the tennis industry first before expanding into other niche sports and international marketplaces. Therefore, networking was an important resource for them. These factors rendered movelabs' network approach perfectly suitable for an investigation on the interpersonal and interorganizational level. Interunit networks were not analyzed as movelab did not yet have separate units.

\subsection{Data Collection}

We began by gaining a detailed understanding of the current literature on our research objective. Then, in line with Soetanto et al. [3], two semi-structured interviews in combination with a network mapping approach of movelabs' network were conducted with one founder of movelab to generate the broadest possible database. In general, network mapping approaches enhanced the experience of the data collection for both the 
interviewer and the interviewee [44]. Coviello [44] also stated that it helped to capture important information about each tie, the content, for example, in a more structured way. Network maps also help frame the change processes that occur in the network in a more systematic manner [38]. Soetanto et al. [3] used this visualization technique themselves to identify influential factors on network change. One network map was created for each interview session with the founder, in accordance with the life-cycle process theory of van de Ven and Poole [37]. The first map represented the network of the startup phase of movelab. The second one represented the growth phase, which movelab had reached. Both network maps were accompanied by semi-structured interviews about the network and the development it went through in the respective phase. The founder himself is a tennis player and tennis coach. He is responsible for all the network activities of the startup since is already embedded in the tennis industry. Thus, within each interview of approximately one hour, he provided deep insights into the network activities of movelab. In addition to and after the interview sessions with the founder of movelab, eight of movelabs' network partners were interviewed. They come from different areas of the tennis industry, including startups that organize events or manufacture tennis products, and also established firms that provide a digital platform for tennis players or award scholarships to college to young tennis players. The length of the interviews varied from nineteen minutes to almost two hours and they were all tape-recorded. An overview of all interview partners is provided in Table 1.

Table 1. Chronological list of the interview partners.

\begin{tabular}{|c|c|c|c|c|}
\hline Interviewee & Firm & Industry Sector & Date of the Interview & Length [hour:min] \\
\hline B1 & movelab & $\begin{array}{c}\text { National startup } \\
\text { Distribution of nutritional supplements } \\
\text { primarily for tennis players }\end{array}$ & $\begin{array}{l}13.08 .2020 \\
15.08 .2020\end{array}$ & $\begin{array}{l}1: 03 \\
1: 38\end{array}$ \\
\hline B2 & & $\begin{array}{l}\text { Internationally established firm } \\
\text { Mediation of sports scholarships in } \\
\text { the USA }\end{array}$ & 24.08 .2020 & $0: 26$ \\
\hline B3 & & $\begin{array}{c}\text { Tennis Coach } \\
\text { Coaching of tennis players at national and } \\
\text { international level }\end{array}$ & 24.08 .2020 & $0: 28$ \\
\hline B4 & & $\begin{array}{c}\text { National startup } \\
\text { Provider of fitness events as a } \\
\text { complement to other sporting events }\end{array}$ & 26.08.2020 & $0: 19$ \\
\hline B5 & & $\begin{array}{l}\text { Nationally established firm } \\
\text { Internet platform for tennis players } \\
\text { in Germany }\end{array}$ & 25.08.2020 & $0: 30$ \\
\hline B6 & & $\begin{array}{l}\text { National startup } \\
\text { Upcycling of old tennis tarpaulins } \\
\text { into accessories }\end{array}$ & 25.08 .2020 & $0: 26$ \\
\hline B7 & & $\begin{array}{c}\text { Internationally established firm } \\
\text { Distribution of sportswear for } \\
\text { different categories }\end{array}$ & 31.08 .2020 & 1:04 \\
\hline B8 & & $\begin{array}{l}\text { Tennis school } \\
\text { Tennis training and distribution of } \\
\text { tennis products }\end{array}$ & 31.08 .2020 & $0: 42$ \\
\hline B9 & & $\begin{array}{l}\text { International startup } \\
\text { Sale of merchandise for tennis players }\end{array}$ & 26.08 .2020 & $0: 39$ \\
\hline
\end{tabular}

The questions of the semi-structured interviews with the network partners were based on their collaboration with movelab. Thus, the statements made by the founder could be verified and the partnerships were illuminated from two sides. In addition, the network partners could report on their own network experiences with other companies to generate 
further information. Therefore, the interview guideline (see in Appendix B) for the network partners was divided into four blocks of questions, such as 'how did you get in touch with movelab' or 'what are the goals of the partnership with movelab and how did they change over time'. The questions were intended to clarify changes in movelabs' network. Therefore, both the three-network components content, government, and structure and the different change patterns served as support for the interview guidelines. The questions were also phrased following the guidelines by Soetanto et al. [3]. Larson [8] also worked with a similar interview approach to collect data for the antecedents of network changes. The data collection took place over one month and all interviews were conducted via Zoom or via telephone.

\subsection{Data Analysis}

After the interviews were conducted, they were transcribed verbatim using MAXQDA software. Using the framework of Mayring [45], the interviews were then subjected to a qualitative content analysis, also utilizing the MAXQDA software. To extract the factors taken from the literature as well as additional recognizable factors from the interviews, the structuring approach was combined with the inductive category formation of Mayring [45]. At first, the transcripts were reduced to passages that described network changes. After this data reduction, a coding guide (Table 2) was created, which served as the comprehensive framework to clearly categorize the various influential factors. An additional category was created for the coding of new aspects, from which new influential factors were subsequently defined inductively. Before the encoding was completed, a test run was conducted to refine or change the categories if necessary. After finishing the data analysis, a second person coded the interviews, and any differences were discussed and solved jointly.

Table 2. Coding Guideline.

\begin{tabular}{|c|c|c|}
\hline Main Categories & Subcategories & Explanation \\
\hline \multicolumn{3}{|c|}{$\begin{array}{c}\text { Resource acquisition } \\
\text { Soetanto, Huang, \& Jack (2018) }\end{array}$} \\
\hline & Technological capability & $\begin{array}{l}\text { Support for the development of new } \\
\text { products is needed. }\end{array}$ \\
\hline & Access to research and development facilities & $\begin{array}{l}\text { Appropriate facilities are needed to develop } \\
\text { innovative products. }\end{array}$ \\
\hline & Investments & Financial means are needed to survive. \\
\hline & Market demand & $\begin{array}{l}\text { Generation of reach and awareness of } \\
\text { potential new customers / existing customers. }\end{array}$ \\
\hline \multicolumn{3}{|c|}{$\begin{array}{l}\text { Knowledge and skill acquisition } \\
\text { Soetanto, Huang, \& Jack (2018) }\end{array}$} \\
\hline & Knowledge about customer demand/ market & $\begin{array}{l}\text { The product must meet the needs of the } \\
\text { customer and it must be sold in the } \\
\text { right marketplaces. }\end{array}$ \\
\hline & Technological change & $\begin{array}{l}\text { The startup must keep pace with } \\
\text { technological development. }\end{array}$ \\
\hline & $\begin{array}{l}\text { Competition and } \\
\text { industrial structure }\end{array}$ & $\begin{array}{l}\text { Startups must be able to stand up to other } \\
\text { companies within the industry. }\end{array}$ \\
\hline & $\begin{array}{l}\text { Regulations, standardization, } \\
\text { and bureaucracy }\end{array}$ & $\begin{array}{c}\text { To increase efficiency, processes are } \\
\text { standardized, or bureaucratic hurdles are } \\
\text { overcome together. }\end{array}$ \\
\hline & $\begin{array}{l}\text { Marketing knowledge } \\
\text { and sales skills }\end{array}$ & $\begin{array}{l}\text { Startups must know how to promote their } \\
\text { products properly, increase the reach and } \\
\text { increase the sales volume. }\end{array}$ \\
\hline
\end{tabular}


Table 2. Cont.

\begin{tabular}{|c|c|c|}
\hline Main Categories & Subcategories & Explanation \\
\hline & $\begin{array}{l}\text { Managerial and } \\
\text { financial skills }\end{array}$ & $\begin{array}{l}\text { Structured organization within the startup } \\
\text { and solid financial plans are necessary. }\end{array}$ \\
\hline \multicolumn{3}{|l|}{$\begin{array}{l}\text { Interpersonal factors } \\
\text { Martin et al. (2019) }\end{array}$} \\
\hline & Trust & Trust enhances closer collaboration. \\
\hline & Development of reciprocity norms & $\begin{array}{l}\text { An unwritten balance of actions and } \\
\text { reactions between two partners. }\end{array}$ \\
\hline & Educational level & $\begin{array}{l}\text { The educational level tends to be directly } \\
\text { proportional to networking skills. }\end{array}$ \\
\hline & Intrinsic motivation & $\begin{array}{l}\text { Intrinsic motivation can have a positive effect } \\
\text { on the search for new opportunities. }\end{array}$ \\
\hline & Prior relations and personal reputations & $\begin{array}{l}\text { The good reputation/ prior relation of a } \\
\text { person can increase the tendency to } \\
\text { cooperate with that person and vice versa. }\end{array}$ \\
\hline & Learning & $\begin{array}{l}\text { Experiences can shape the process } \\
\text { of networking. }\end{array}$ \\
\hline & Reduction of uncertainty & $\begin{array}{l}\text { Founders tend to collaborate with each other } \\
\text { in uncertain situations. }\end{array}$ \\
\hline & Identity-based similarity & $\begin{array}{l}\text { Two founders with similar mindsets or } \\
\text { situations tend to collaborate. }\end{array}$ \\
\hline Main categories & Subcategories & Explanation \\
\hline \multicolumn{3}{|c|}{$\begin{array}{l}\text { Interorganizational factors } \\
\text { Martin et al. (2019) }\end{array}$} \\
\hline & Risk-taking propensity & The risk that a new tie entails must be taken. \\
\hline & Joint innovation projects & $\begin{array}{l}\text { The implementation of innovation projects in } \\
\text { isolation can be challenging. }\end{array}$ \\
\hline & Added value & Ties must generate added value. \\
\hline & Improvement of legitimacy & $\begin{array}{l}\text { Startups must assert themselves within } \\
\text { the industry. }\end{array}$ \\
\hline & Geographical proximity & $\begin{array}{l}\text { The partners are in the same } \\
\text { geographical area. }\end{array}$ \\
\hline & Mutual economic advantage & $\begin{array}{c}\text { Both partners profit economically from } \\
\text { the tie. }\end{array}$ \\
\hline & Firm reputation & $\begin{array}{l}\text { The good reputation of a firm/ startup can } \\
\text { increase/ decrease the tendency } \\
\text { towards collaboration. }\end{array}$ \\
\hline & Operational and strategic integration & Joint processes or strategies are developed. \\
\hline & Social media & $\begin{array}{l}\text { Digital platforms that enable to represent the } \\
\text { firm/ startup. }\end{array}$ \\
\hline $\begin{array}{l}\text { Additional category } \\
\text { Mayring [45] }\end{array}$ & & $\begin{array}{c}\text { Text passages that cannot be assigned to any } \\
\text { category above. }\end{array}$ \\
\hline
\end{tabular}

\section{Findings}

At first, movelabs' network development was briefly explained using the two network maps. Figures 1 and 2 show that the network of movelab has changed significantly from the startup phase to the growth phase. As shown, the number of network partners and the density of the network increased, even though some ties of the startup phase were 
dissolved. The second noticeable aspect was that the partners, with whom they were strongly connected, represented through the red borders, have changed over time.

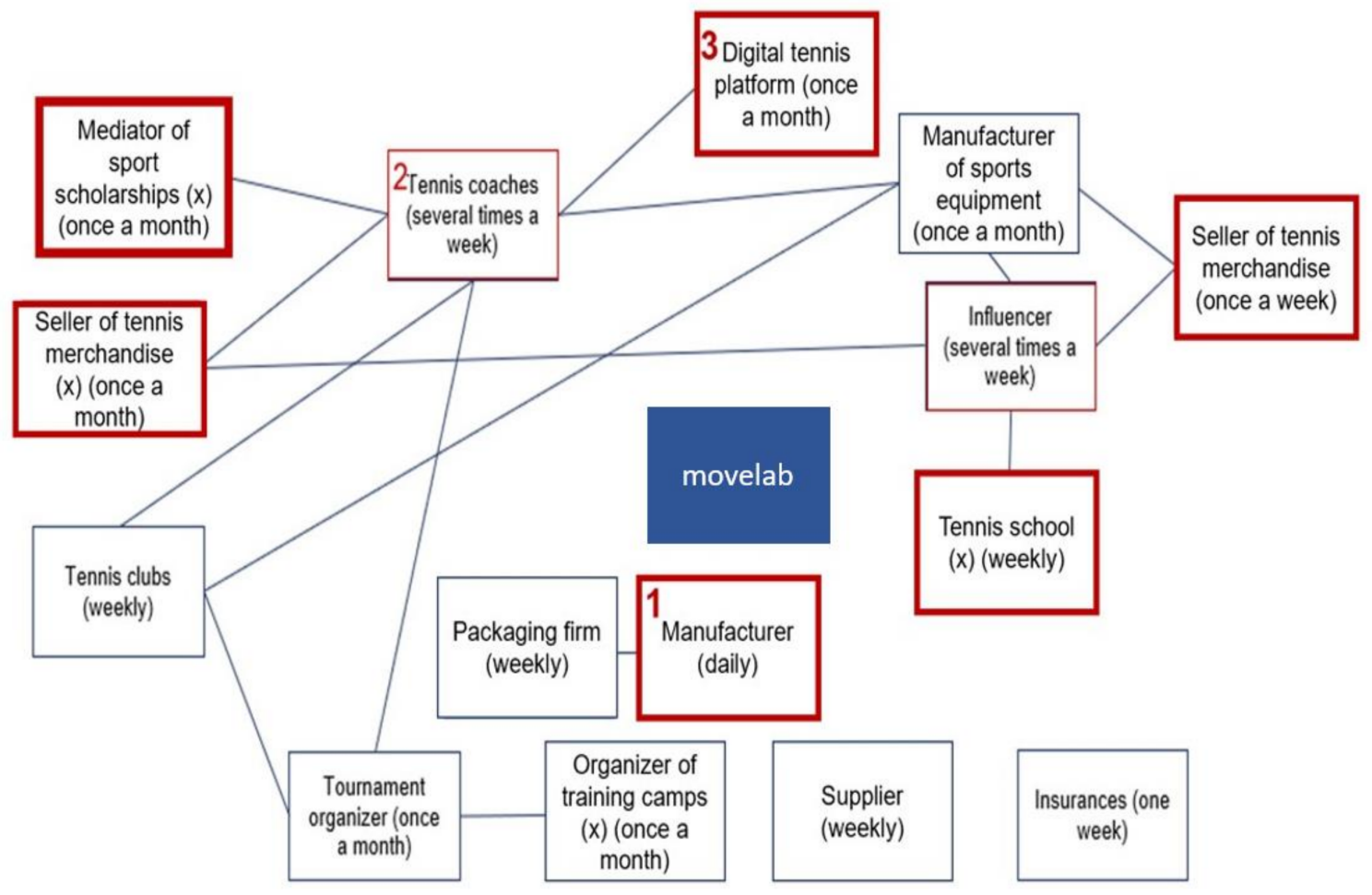

Figure 1. Network of movelab in the startup phase.

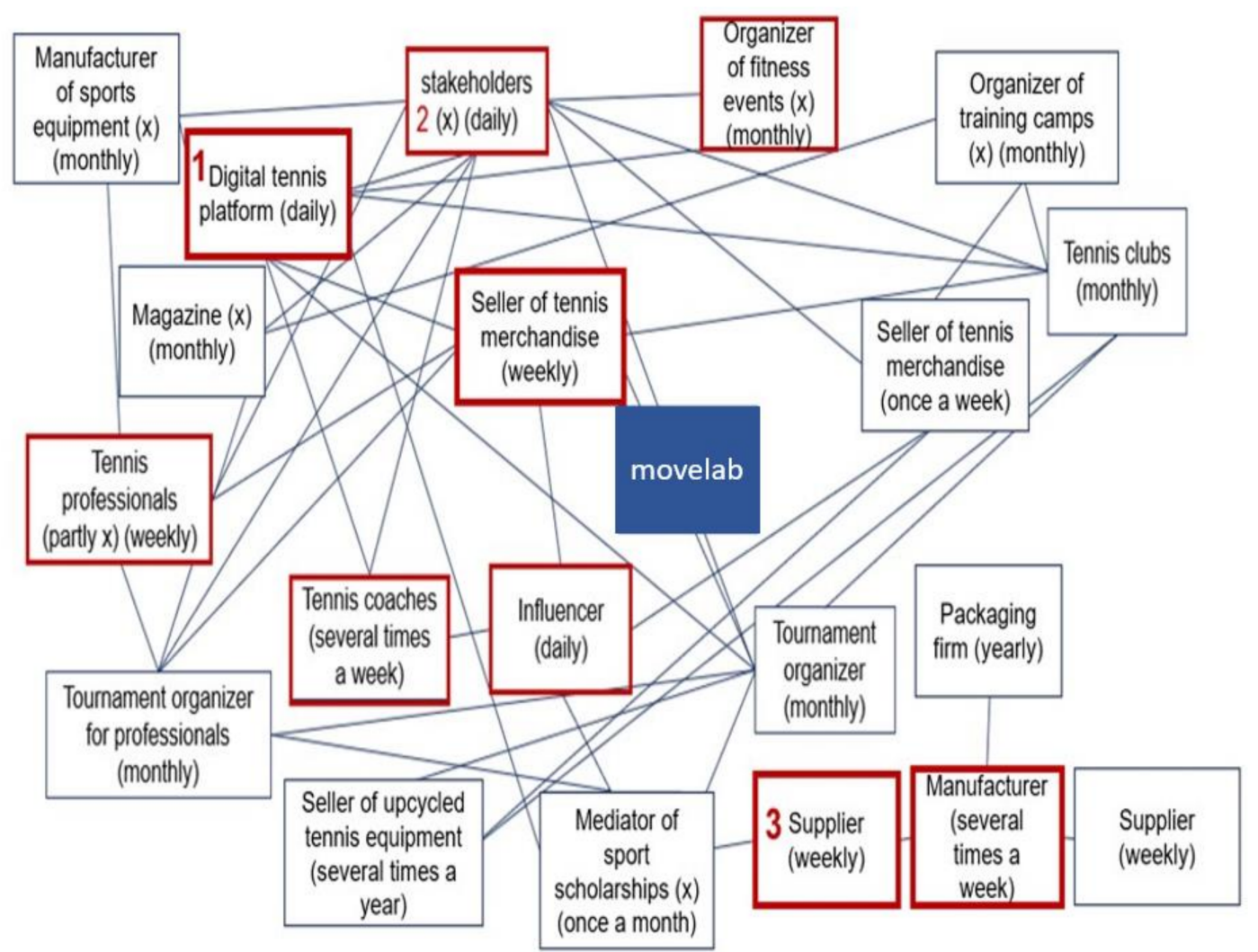

Figure 2. Network of movelab in the growth phase. 
Transferring to the results of the encoded interviews, tie creation was the most frequently observed change pattern. This was followed by network changes through changes in the tie strength. Tie deletion was the least-mentioned change pattern. After this short introduction to the different networks of movelab, the findings of the interviews, as shown in Table 3, were discussed. The factors that could not be confirmed were not mentioned at all or only mentioned up to four times in the interviews.

Table 3. Applicability of factors from the literature and newly investigated factors.

\begin{tabular}{|c|c|c|}
\hline Occurring Factors from Literature & Non Occurring Factors from Literature & Newly Identified Factors \\
\hline Market demand & Investments & Financial means \\
\hline Technological capability & $\begin{array}{l}\text { Access to research and } \\
\text { development facilities }\end{array}$ & $\begin{array}{l}\text { Versatile and new content/offers for } \\
\text { new or existing customers }\end{array}$ \\
\hline Managerial knowledge and financial skills & $\begin{array}{l}\text { Regulations, standardization, and } \\
\text { bureaucracy }\end{array}$ & Time constraints within the startup \\
\hline Marketing knowledge and sales skills & Competition and industrial structure & Unfulfilled expectations \\
\hline Knowledge about customer demand/market & Technological change & Events \\
\hline Identity-based similarity & Reduction of uncertainty & Common target group \\
\hline Learning & Educational level & Firm development \\
\hline Prior relations and personal reputations & Operational and strategical integration & Potential for further ties \\
\hline Intrinsic motivation & Geographical proximity & $\begin{array}{l}\text { Short communication channels and } \\
\text { decision processes }\end{array}$ \\
\hline Development of reciprocity norms & Risk-taking propensity & \\
\hline \multicolumn{3}{|l|}{ Trust and friendship } \\
\hline \multicolumn{3}{|l|}{ Social Media } \\
\hline \multicolumn{3}{|l|}{ Mutual economic advantage } \\
\hline \multicolumn{3}{|l|}{ Improvement of legitimacy } \\
\hline \multicolumn{3}{|l|}{ Added value } \\
\hline Joint (innovation) projects & & \\
\hline
\end{tabular}

\subsection{Resource Acquisition}

Within the first main category, resource acquisition, the factor market demand was most frequently mentioned and strongly associated with tie creation. To increase market demand, it was important to extend the reach and to generate awareness among the customers. Therefore, the interviewed startups created ties to combine their reaches as stated by interviewee B9: 'Then, of course, give each other reach (...) and, as a final aspect, the sales idea that we can perhaps use cross-selling aspects through the sales of the bars. That maybe the person who buys the bar from us will spontaneously buy a shirt from our collaboration partner with it.' Technological capability is also a factor, and was often included in the transcripts and caused tie creations. On the one hand, movelab created several ties to outsource the production of their products. On the other hand, due to their increasing experience, they were asked by a network partner to develop a product themselves as interviewee B9 explained: ' [ . . . ] they are absolute specialists in the development of such products, where we have no clue.'

The first newly identified factor influencing tie creation was the provision of versatile content or offers for new or existing customers. For instance, interviewee B5 relied on this concept as one reason for the collaboration with movelab, as he explained: 'And on the other hand it is always interesting for us to provide new content for our tennis players and to keep our target group busy.' Another new factor, that was mainly related to tie creation, was financial means. On the one hand, ties were created to save financial means since those collaborations were not based on cash flow. On the other hand, ties were created 
to increase the financial means of the startup. The last aspect was the startups' shortage of financial means, which either was a reason for new tie creation 'to combine the power of two startups' as stated by interviewee B6 or tie deletion, because the budget was not sufficient to maintain a collaboration.

\subsection{Knowledge and Skill Acquisition}

The factors of managerial knowledge and financial skills, marketing knowledge and sales skills, and knowledge about customer demand/ market were all mentioned several times throughout the interviews. One example that was given by interviewee B1 was the entry of the two shareholders of movelab who joined in the growth phase of the startup and provided new knowledge: 'When they joined, we changed our whole store system. We automated everything a lot more, so that the company could really grow faster, and processes were simplified.' Additionally, movelab contacted its marketing-experienced manufacturer regarding correct health claims on the packaging of its products and, thus, their tie strengthened. To gain knowledge about the customer demand, movelab integrated tennis players such as interviewee B7 into the product development process to acquire feedback from a potential end customer, which enhanced the strength of the tie: 'Plus, that I was able to test it actively on the court. It is all about things like whether I get very thirsty when I eat the bar, or things like that.' There were no new factors identified within this main category.

\subsection{Interpersonal Factors}

Prior relations and personal reputations significantly drove new tie creation, as affirmed by interviewee B1: 'That was really an advantage, which I still notice, that this tennis niche or every other sports niche, if you are embedded you really get a lot of advantages from it $[\ldots]$. And that is how a network is built, because you are recommended to others and $[. .$.$] contacts automatically increase.' Another influential factor on tie creation that$ was mentioned by half of the interviewees was identity-based similarity. Interviewee B9 explained: '[ ... ] [T]wo young brands or two young companies, that basically fits.' The development of reciprocity, trust, and the newly added component friendship or intrinsic motivation all benefited the strength of ties. Additionally, learning both caused decreases and increases in the strength of ties. Furthermore, a newly identified factor defined as time constraints within the startup only had an adverse effect on the strength of ties. Interviewee B5 summarized it as follows: 'This is mostly due to us, however, because we sometimes do not have the resources to take care of all partnerships properly.'

\subsection{Interorganizational Factors}

The most outstanding factor within the last main category was the social media factor. Social media represented a new way to get to know partners, as claimed by interviewee B6: 'That has become common practice via Instagram in our case, [ . . ] it works via messages there, [ . . . ].' It also provided new opportunities for collaboration and, hence, strengthened ties. Other factors from the literature mainly drove tie creations such as improvement of legitimacy, added value, and the firm reputation. Firm reputation could be expanded on the new aspect quality of products, since good quality of products drove other startups to collaborate with this startup, as expressed by interviewee B4: 'Movelab is official nourishing partner of a German internet platform for tennis players. [ ... ] this is not a garage dealer, but there is a brand behind it. And the product has a really high quality.' A newly identified factor that drove tie creation was a common target group of both partners. The second newly identified factor driving tie creation was the potential for further tie creation. The tie of movelab to a magazine in the tennis industry helped them to reach out to further contacts, as explained by interviewee B1: 'This tennis magazine cup to which numerous companies were invited, some of which are now here on the network card. You could really maintain the contacts there and find new contacts, like our shareholders, like the provider of the German internet platform for tennis players.' 
A factor that drove changes within the strength of a tie was joint innovation projects, which was renamed for this paper as joint projects, because many of the interviewees had non-innovative joint projects. For instance, joint product development strengthened the tie, especially in the phase of product launch and advertisement. Both tie strength and tie creation were driven by mutual economic advantage, but also by the new factors defined as events and short communication channels and decision processes.

Unfulfilled expectations emerged as a factor associated with tie deletion. Nearly all the interviewees have mentioned this factor as a reason for tie deletion. Another new aspect that served as an influential factor for tie deletion, tie creation, and well as changes in the tie strength was firm development. On the one hand, startups tended to collaborate with other firms to grow further. On the other hand, existing ties decomposed if the two partners developed in different directions in terms of goals, strategies, and mindsets. These findings are discussed below.

\section{Discussion}

In the following, we discuss our findings in light of the current literature. We then explain our theoretical contributions and managerial implications, and conclude with our study's limitations and future research.

\subsection{Confirmed Factors from the Literature}

The influence of social media on tie creation and tie strength elaborated by Drummond et al. [9] was strongly confirmed by the interviewees. While Drummond et al. [9] focused on the platforms Facebook and Twitter, the platform most frequently used by the interviewed firms and startups was Instagram, as explained by interviewee B7: 'Because I think I get all the information I need from Instagram, because you can see how this startup works at a glance. They have a certain language, a certain appearance to the outside.'

An interesting aspect that interviewee B7 added was that the presence of a profile on the platform LinkedIn could provide a more professional appearance of startups. This, in turn, could encourage new tie creations since such a profile could represent a higher level of respectability. Furthermore, for movelab it is strategically important to build ties with influencers on social media platforms, as explained by interviewee B1: 'But we are also in constant contact with influencers and many micro-influencers, as I like to call them, sometimes they bring us more than someone who has twenty thousand followers, but you know that of the twenty thousand, eighteen thousand follow only because they somehow find the pictures beautiful and not the real content behind them.'

Thus, the network of movelab could be expanded by social media to include a further type of network partners. Consequently, the social media factor benefits both creation of awareness and expansion of reach among customers, which are characteristic components of the next influential factor on tie creation: market demand. This can be associated with the work of Brüderl and Preisendörfer [14], in which they researched the impact of networks on the success of a startup and found that, in order to survive as a startup, it is necessary to attract enough customers [14], consistent with interviewee B1: 'Through a German internet platform for tennis players we have now a reach of over two hundred thousand tennis players, to whom we reach out via the newsletter and that is [ ... ] the largest tennis network in Germany.' In summary, nowadays, it is very important for startups to expand the market demand through ties with the help of various digital solutions.'

Another factor driving the creation of the tie to the provider of a German internet platform for tennis players was prior relations and personal reputations, as the stakeholders of movelab already knew the managing directors of the provider of a German internet platform for tennis players. Many of the interview partners such as interviewee B5 stated that 'the tennis industry is a very, very small niche. Nearly everyone knows each other.' Hence, this factor, evaluated by Larson [8], could be confirmed. Another reinforcing aspect about this factor was provided by interviewee B1. Even though movelabs' initial approach was to also contact tennis coaches via cold calls, they quickly noticed that this type of 
networking was not as effective as contacting already-known tennis coaches. This, in turn, refers to the learning factor $[7,11]$. The founder of movelab learned from the experiences within the existing ties. However, rather than forming new and diverse ties in the network as claimed by Brass et al. [11], movelab adapted the intensity, and consequently the strength of certain ties strategically [35]. Interviewee B5 explained, for example, that the tie between their firm and movelab intensified when they realized that isolated actions were not having the desired effect.

In contrast, movelab weakened their tie to tennis coaches when they experienced that the promotion of their products through this tie was not as successful as they initially thought. Staying within the main category of interpersonal factors, the assumption of Larson [8] that trust affected increases in tie strength was confirmed by the interviews. For instance, interviewee B6 mentioned: 'For example, before the first event, where we did not know each other, this was of course a different way of talking to each other than it is today. You somehow exchange views on some topics more openly or you exchange difficulties you face.' Not only does trust drive the exchange of success-critical assets as Uzzi [23] already assumed, it also furthers the exchange of strategical information. In some ties, this trust developed into friendship between the founder of movelab and the network partner, which is why the factor of trust was expanded to include friendship.

Besides this, the level of identity-based similarity also drove tie creations, as expressed by interviewee B6: 'I think that especially when it comes to two startups. That means that neither of us have a huge [amount] of people or budget.' Therefore, it is less the social or ethnic background, as described by Ahuja et al. [7] or by Zelekha and Dana (2019), but much more similar problems and similar goals that create such ties. Thus, the factor identified by Ahuja et al. [7] is applicable in this paper, even if not to the full extent. The interviewees mentioned the term added value several times throughout the interviews. Ahuja et al. [7] stated that this added value serves as a reason for all kinds of network changes, such as tie creation, tie deletion, tie strengthening, and tie weakening. The interviewees, however, most frequently stated that added value was an important factor for the creation and strengthening of ties, but only one interviewee B9 mentioned that added value was a motivating factor for tie deletion as well: 'Personally, I do not think it is bad or even quite good that ties dissolve and then you do something new. [ ... ] Because you create space for new ideas again.' In line with the observations of Galaskiewicz [5], an important aspect for the interview partners in terms of tie creation was the improvement of legitimacy. However, an interesting aspect was that for the startup movelab this factor was more important in the startup phase, as explained by interviewee B1: 'Before that we were not known at the very beginning. And that is when [ . . ] we were happy to be surrounded by big brands. [ ... ] And now we are slowly becoming a brand, people know us better and better and then you do not have to surround yourself with other big brands anymore.' Therefore, this factor was particularly influential in the startup phase.

\subsection{Unsupported Factors from Prior Literature}

Besides the findings supporting the literature, there are also results contrary to the literature. An outstanding aspect is that reduction of uncertainty was not mentioned by any interviewee, even though it is widely known in the entrepreneurial literature that entrepreneurs face a greater degree of uncertainty than established firms [46]. The reason for this could be that interview partners are more likely to share goals and visions with unknown interviewers than uncertainties, as these may contain strategical information. The factors of access to research and development facilities and technological change determined by Soetanto et al. [3] could not be confirmed by the interviewees. This can be explained by the fact that movelab and most of their network partners do not provide highly technology-based products whose development requires significant technical knowledge or is influenced by technological change. Due to movelabs' strategy to grow with little capital and without external investments, the factor investment assumed by Soetanto et al. [3] could not be identified in this paper. 
Furthermore, contrary to Martin et al. [6] the educational level of any network partner was not mentioned at all by the interviewees, although many of the interview partners, for instance the founder of movelab, have a university degree. Only two of the network partners of movelab contributed to the factor regulations, standardization, and bureaucracy, and therefore it was not considered as applicable. For instance, interviewee B7 mentioned that movelab might have created the tie between the startup and the firm to evade regulations, standardization, and bureaucracy, since they did not sign any contract. This brings up the new aspect that startups not only need partners to help them deal with regulations and standards, as Soetanto et al. [3] already stated, but also that explicitly informal ties are established to avoid these standards and bureaucratic hurdles. The last factor which could not be confirmed within the paper was geographical proximity, which is probably linked to the fact that, nowadays, the digital tool landscape and different social media platforms serve as an efficient basis for digital collaboration [9]. Only one aspect was mentioned that limited the flexibility of a collaboration, expressed by interviewee B8: 'The fact that Bamberg and Haßfurt is not a long distance. This is not something that I have to order from the catalog, but I call, and if necessary, I can pick it up quickly by myself.' For the delivery of physical products, geographical proximity can therefore be advantageous. In summary, not all factors found in both the overall organizational and entrepreneurial literature could be confirmed in this paper.

\subsection{Newly Identified Factors}

Finally, after evaluating the applicability of the factors identified in previous literature, the new factors investigated within this paper will be discussed. Especially in times of digitalization and social media [47], the interviewees stated that it is becoming more important to continuously provide customers with new, varied content and worthwhile offers. Additionally, this was driven by new digital business models in which new added value must be communicated to the customers, as interviewee B5 described: 'But you can also become a premium member for a fee. [ ... ] You get shopping vouchers from other partners, for example Tennis Warehouse and we are always looking for new offers for our premium members.' This was the reason for the firm entering a tie with movelab.

Consequently, provision of new and versatile content and offers for new or existing customers can be identified as a factor influencing the creation of ties and, sometimes, also the strengthening of ties since even existing ties initiated new projects to generate new content. Another reinforcing aspect for this influential factor was the COVID-19 pandemic, as expressed by interviewee B9: 'And then [ ... ] movelab once again came to my mind. Simply because, I think it was also during COVID-19. [ ... ] The tennis market was dead then too because nobody played. And I was looking for content.' Even though Kuckertz et al. [48] argued that startups could adapt to such crisis situations much faster, they still suggested that they should actively use their network to deal with the special situation. However, even in an offline world, it is becoming increasingly important to present one's own brand in a harmonious environment, which mainly drove the interviewed firms and startups to include movelab as a new partner into their events.

This finding complemented the work of Drummond et al. [9], in which they stated that ties were only strengthened through joint events. Especially with regard to the organization of joint events, short communication channels and decision-making processes had a positive influence both on the strength of ties and tie creations, as stated by interviewee B9: 'Young brand, which is also open for collaboration and [ ... ] also because it is very important that we have brands with whom we can implement such a project quickly and easily. This is often difficult in larger firms. Because it takes ages to get through all the authorities.' Thus, this serves as an influential factor that is particularly applicable within entrepreneurial research.

A factor that impacts both tie creations and tie deletions is financial means. This is a key factor in sustainable business development [49]. Startups are often constrained by their budget, which drives many of them to look for new investments [3,50,51]. Since 
movelab aims to grow without external capital, they found another way to reach their goals. They created ties with other startups or firms that were not purely based on cash flow. Of course, many of their ties were also aimed at increasing the financial means, as interviewee B1 explained: 'So one thing at the moment is clearly the provider of a German internet platform for tennis players (...), because it (...) has created completely new possibilities for us to reach our end customers. [ ... ], they have a platform with over two hundred thousand tennis members and are well known in Germany. Therefore, it was extremely important for us and has almost tripled our current revenue since the start of the collaboration.'

Finally, financial means also caused tie deletions due to the above mentioned budget constraints, as interviewee B9 suggested: 'They were too expensive. [ ... ] We kind of had a special welcome startup deal or something for the first eighteen months and then the contract ran out.' Another factor that caused tie deletion was unfulfilled expectations. This factor occurred in situations such as missing deadline compliance, one sided commitment, dissatisfaction of the customers, and unsuccessful joint projects. Deadline compliance is an important aspect in terms of collaboration, since the partner relies on it, as expressed by interviewee B6: 'And that is one of the most important things, when someone sets a deadline, that you are finished by that date and there was, for example, a tie where $[\ldots]$ at the beginning there was of course trust [ ... ]. Of course, this has decreased, because you cannot work on such a basis [ ... ]. 'Besides this reliability, it is also relevant that both sides put effort into the tie, as explained by movelabs' network partner B7: 'It all sounds great, but of course if the implementation is not done by both sides, then it is just bad. [ ... ] If one side does not commit to the partnership it is always bad.' She explicitly mentioned, that for startups which are very open-minded and work in a less bureaucratic way, reliability and constant commitment was even more important to maintain a tie successfully. An overview of the influential factors discussed in the sections above is given in Table 4 .

Table 4. Influential factors on the different types of network changes from the discussion.

\begin{tabular}{ccc}
\hline Influential on Tie Creation & Influential Factors on Tie Strength & Influential Factors on Tie Deletion \\
\hline Social media & Learning & Financial means \\
\hline Market demand & Trust and friendship & Unfulfilled expectations \\
\hline Identity-based similarity & Added value & \\
\hline Prior relations and personal reputation & $\begin{array}{c}\text { Short communication channels and } \\
\text { decision-making processes }\end{array}$ & \\
\hline Improvement of legitimacy & Joint events \\
\hline Financial means & \\
\hline Joint events & \\
\hline Short communication channels and \\
decision-making processes
\end{tabular}

\section{Conclusions}

The results of this research provide both theoretical contributions and managerial implications centering on factors that influence network changes for sustainable business development. These are discussed in the next sections.

\subsection{Theoretical Contributions}

Whereas previous research focused on the factors that influence tie creation and the strength of the tie, this paper also investigated factors for tie deletion. Thus, for a comprehensive evaluation of network changes, all three patterns should be taken into consideration in future research. Furthermore, previous papers used different categories to cluster the 
influential factors on network changes. As can be seen, the four main categories defined in this paper, namely resource acquisition, knowledge and skill acquisition, interpersonal factors, and interorganizational factors also cover all new factors investigated within the research. This implies that the four main categories are comprehensive and could serve as a first standardized framework for future theoretical work. Apart from that, this paper included the network partners of the investigated startup into the interviews in order to generate a broader database. This approach provided multi-layered and multi-perspective insights. The methodological approach of mapping the networks of movelab, also applied by Soetanto et al. [3,30], was helpful for the founder to memorize the network of their startup phase and as well as helpful for the data analysis to perceive the changes within the network immediately.

\subsection{Managerial Implications}

Besides the theoretical impact of this paper, the first managerial implication should be to use more renowned social media platforms to network with other firms since this strengthens the startups' professional reputation and, thus, has a positive influence on the creation of new ties. In general, the social media representation of the startup is important for the attraction of potential network partners. Thus, startups should try to be constantly present in social media and use posts to market their values and convictions strategically. Another factor that drove partner firms of movelab to collaborate with the startup was the short communication channel and decision path. Therefore, startups should try to keep these short and simple processes despite team expansion and growth.

Furthermore, startups often seek additional investments to grow further. As can be determined using the case of movelab, another way to grow is to create open-minded and diverse ties with different partners to reach the startup's goals without external investments. Creating new ties is also a satisfactory way to offer the existing or potential customers new and versatile content to build up a reputation. However, besides new tie creation, a focus for startups should also be to maintain already-existing ties since this factor was indicated as influential for the changes in tie strength up to tie deletion. In addition, startups should follow deadlines within the tie to meet the expectations of the partner and avoid tie deletion. This, of course, applies to both partners. The last factor causing tie deletion that startups can actively tackle is one-sided commitment. The amount of effort invested into the tie is directly linked to the satisfaction of both partners. Consequently, for startups, it is important to discover a maintainable number of network partners with whom they can actively achieve their goals at the same time.

\subsection{Limitations and Further Research}

This paper had certain limitations. First, this paper investigated the factors based on the single case of the startup movelab. Due to certain characteristics of movelab, such as growing on low capital, a generalization of the findings is challenging [43]. Therefore, a next step could be to replicate this study based on a multiple-case study approach using startups of different industries with varying growth and business strategies. Regarding the unconfirmed factors of investment and technological change, especially in high-tech industries, a renewed execution of the study could provide interesting results. Furthermore, the database only covered the startup phase and the growth phase of movelab since movelab is currently in this second stage. Future literature could assess the applicability of the factors within later phases of startups, such as in the maturity stage. Moreover, it would be especially interesting whether the factors causing network changes within unsuccessful startups are directly linked to their decline or death.

Besides that, the impact of external shocks, such as the COVID-19 pandemic, on network changes for sustainable business development should be investigated in greater detail [52]. Additionally, as already postulated by Soetanto et al. [3], interpersonal factors should be further investigated since the educational level [6] and the reduction of uncertainty [5] could be more important in startups embedded into other industries. 
Author Contributions: Conceptualization, J.K., P.M.B. and F.J.R.; methodology, J.K. and P.M.B.; data collection and analysis, J.K.; writing — original draft preparation, J.K.; writing—review and editing, P.M.B. and F.J.R. All authors have read and agreed to the published version of the manuscript.

Funding: This research received no external funding.

Institutional Review Board Statement: Not applicable.

Informed Consent Statement: Not applicable.

Data Availability Statement: Not applicable.

Conflicts of Interest: The authors declare no conflict of interest.

\section{Appendix A}

Table A1. Framework for influential factors on network changes.

\begin{tabular}{|c|c|}
\hline Main Categories & Subcategories \\
\hline \multirow{2}{*}{\multicolumn{2}{|c|}{$\begin{array}{c}\text { Resource acquisition } \\
\text { Soetanto, Huang, \& Jack (2018) }\end{array}$}} \\
\hline & \\
\hline & Technological capability \\
\hline & (Access to research and development facilities) \\
\hline & (Investments) \\
\hline & Market demand \\
\hline & Financial means \\
\hline \multicolumn{2}{|l|}{$\begin{array}{l}\text { Knowledge and skill acquisition } \\
\text { Soetanto, Huang, \& Jack (2018) }\end{array}$} \\
\hline & Knowledge about customer demand/market \\
\hline & (Technological change) \\
\hline & (Competition and industrial structure) \\
\hline & $\begin{array}{c}\text { (Regulations, standardization, and } \\
\text { bureaucracy) }\end{array}$ \\
\hline & Marketing knowledge and sales skills \\
\hline & Managerial and financial skills \\
\hline \multicolumn{2}{|l|}{$\begin{array}{l}\text { Interpersonal factors } \\
\text { Martin et al. (2019) }\end{array}$} \\
\hline & Trust and friendship \\
\hline & Development of reciprocity norms \\
\hline & (Educational level) \\
\hline & Intrinsic motivation \\
\hline & Prior relations and personal reputations \\
\hline & Learning \\
\hline & (Reduction of uncertainty) \\
\hline & Identity-based similarity \\
\hline & Time constraints within the startup team \\
\hline Main categories & Subcategories \\
\hline
\end{tabular}


Table A1. Cont.

\begin{tabular}{cc}
\hline Main Categories & Subcategories \\
\hline $\begin{array}{c}\text { Interorganizational factors } \\
\text { Martin et al. (2019) }\end{array}$ & (Risk-taking propensity) \\
\hline & Joint innovation projects \\
\hline Added value \\
\hline Improvement of legitimacy \\
\hline (Geographical proximity) \\
\hline Mutual economic advantage \\
\hline (Operational and strategic integration) \\
\hline Social media \\
\hline Unfulfilled expectations \\
\hline Firm development \\
\hline Events \\
\hline Potential for further tie creation \\
\hline Common target group \\
\hline
\end{tabular}

\section{Appendix B. Interview Guidelines}

Interview Questionnaire-Founder

Startup Phase

Structural questions:

- $\quad$ Please draw a sketch of your network during the concept generation phase.

- Please draw lines between the contacts that are connected.

- Please draw arrows that represent the direction of the connection.

Relational questions:

- Please use red color to circle the strong ties.

- What was the content/main goal of each tie?

- How often do you communicate with the certain partner?

- Which tie was the most important one within this phase?

- What was the content of this tie?

- Why was it the most important tie?

- Where did you meet this partner?

- When and why was this tie established?

Questions about network changes

- Which partner helped you to generate your business idea?

- Where did you meet your initial partners? Did you contact them for economic reasons, or did you know them personally?

- Which benefits provided each tie for the startup?

Questions about motives and goals

- Which tasks or problems were solved in the startup phase?

- How were these problems solved?

- Which partners were involved in the solution process?

- Which goals did you have for the startup in the startup phase? 
- Were there any partnerships within your network that inspired you to move on to other directions?

Growth Phase

Structural questions

- Please draw a sketch of your network during the growth phase. You can refer to the previous sketch of the network from the first phase.

- Please draw lines between the contacts that are connected.

- Please draw arrows that represent the direction of the new connection.

Relational questions

- Please use red color to circle strong ties.

- What is the content/ main goal of each new tie?

- How often does the startup communicate with the new partners?

- What is the most important tie in the growth phase?

- What is the content of this tie?

- Why was it the most important one?

- Where did you meet this partner?

- When and why was this tie established?

Already established ties

- Can you tell me about goals or contents that changed within ties? Why did they change? Deleted ties

- Why was this tie deleted?

New ties

- In which situations did you look out for new partners?

- Where did you meet your new partner?

- Why did this tie occur in this phase?

- Can you tell me about failed tie creation approaches?

Questions about motives and goals

- Which tasks or problems are you trying to solve in the current phase?

- How are you trying to solve these problems?

- Which partners are involved in the solution process?

- Which goals do you currently have for the startup? If the goals changed in contrast to the startup phase, why did they change?

- Are there any partnerships within your network that inspired you to move on to other directions?

Interview Questionnaire-Network partner Key data

- How and where did you meet movelab?

- Who initiated the tie?

- How long did you work and collaborate with movelab?

- Why was the cooperation with movelab approved initially?

- How regularly do you have contact with movelab? Has the regularity changed during the collaboration (daily, once a week, more than once a week, monthly, yearly)?

- Can you tell me about contacts to companies that also have contact with movelab? If so, how have they developed over time?

Questions about the tie to movelab

- What aspects does your tie to movelab include? How and why has the content of your tie to movelab changed?

- What are the goals of your tie to movelab? How and why have the goals of your tie changed compared with the beginning? 
- Which tasks or problems have you already been able to master together with movelab?

- What benefits does the tie to movelab have?

- Which aspects of the tie to movelab do you find particularly good and why?

- How has the basis of trust with movelab developed over time and, above all, why has it developed in this way?

Questions about the own network experiences

- Can you tell me about goals or content of other ties (with startups) that have changed over time? Why have they changed?

- Can you tell me about weak ties that have evolved into strong ties (or vice versa)? Why have they developed in this way?

- How has the basis of trust developed over time with the longer ties?

New ties

- Why are new ties added to the network?

- Where do you get to know these partners?

- What advantages do new ties offer?

- What are the reasons why ties in the network disappear? Can you tell me about your own experiences?

\section{References}

1. Jack, S.; Dodd, S.D.; Anderson, A.R. Change and the development of entrepreneurial networks over time: A processual perspective. Entrep. Reg. Dev. 2008, 20, 125-159. [CrossRef]

2. Aldrich, H.; Zimmer, C. Entrepreneurship Through Social Networks. In The Art and Science of Entrepreneurship; Sexton, D.L., Smiler, R.W., Eds.; Ballinger: Cambridge, MA, USA, 1986; Volume 33, pp. 3-23.

3. Soetanto, D.; Huang, Q.; Jack, S. Obstacles, Networking Approaches and Entrepreneurial Network Changes. Eur. Manag. Rev. 2018, 15, 171-189. [CrossRef]

4. Jack, S.; Moult, S.; Anderson, A.R.; Dodd, S. An entrepreneurial network evolving: Patterns of change. Int. Small Bus. Journal: Res. Entrep. 2010, 28, 315-337. [CrossRef]

5. Galaskiewicz, J. Interorganizational Relations. Annu. Rev. Sociol. 1985, 11, 281-304. [CrossRef]

6. Martin, D.; Romero, I.; Wegner, D. Individual, Organizational, and Institutional Determinants of Formal and Informal Inter-Firm Cooperation in SMEs. J. Small Bus. Manag. 2018, 57, 1698-1711. [CrossRef]

7. Ahuja, G.; Soda, G.; Zaheer, A. The Genesis and Dynamics of Organizational Networks. Organ. Sci. 2012, 23, 434-448. [CrossRef]

8. Larson, A. Network Dyads in Entrepreneurial Settings: A Study of the Governance of Exchange Relationships. Adm. Sci. Q. 1992, 37, 76. [CrossRef]

9. Drummond, C.; McGrath, H.; O'Toole, T. The impact of social media on resource mobilisation in entrepreneurial firms. Ind. Mark. Manag. 2018, 70, 68-89. [CrossRef]

10. Koka, B.R.; Madhavan, R.; Prescott, J.E. The Evolution of Interfirm Networks: Environmental Effects on Patterns of Network Change. Acad. Manag. Rev. 2006, 31, 721-737. [CrossRef]

11. Brass, D.J.; Galaskiewicz, J.; Greve, H.R.; Tsai, W. Taking Stock of Networks and Organizations: A Multilevel Perspective. Acad. Manag. J. 2004, 47, 795-817. [CrossRef]

12. ODonnell, A.; Gilmore, A.; Cummins, D.; Carson, D. The network construct in entrepreneurship research: A review and critique. Manag. Decis. 2001, 39, 749-760. [CrossRef]

13. Johannisson, B.; Mønsted, M. Contextualizing Entrepreneurial Networking. Int. Stud. Manag. Organ. 1997, 27, 109-136. [CrossRef]

14. Brüderl, J.; Preisendörfer, P. Network Support and the Success of Newly Founded Business. Small Bus. Econ. 1998, 10, $213-225$. [CrossRef]

15. Hite, J.M. Evolutionary Processes and Paths of Relationally Embedded Network Ties in Emerging Entrepreneurial Firms. Entrep. Theory Pr. 2005, 29, 113-144. [CrossRef]

16. Hoang, H.; Antoncic, B. Network-based research in entrepreneurship: A critical review. J. Bus. Ventur. 2003, 18, 165-187. [CrossRef]

17. Slotte-Kock, S.; Coviello, N. Entrepreneurship Research on Network Processes: A Review and Ways Forward. Entrep. Theory Pr. 2010, 34, 31-57. [CrossRef]

18. Butler, J.E.; Hansen, G.S. Network evolution, entrepreneurial success, and regional development. Entrep. Reg. Dev. 1991, 3, 1-16. [CrossRef]

19. Davidsson, P.; Honig, B. The role of social and human capital among nascent entrepreneurs. J. Bus. Ventur. 2003, 18, 301-331. [CrossRef]

20. Watson, J. Modeling the relationship between networking and firm performance. J. Bus. Ventur. 2007, 22, 852-874. [CrossRef] 
21. Lechner, C.; Dowling, M. Firm networks: External relationships as sources for the growth and competitiveness of entrepreneurial firms. Entrep. Reg. Dev. 2003, 15, 1-26. [CrossRef]

22. Birley, S. The role of networks in the entrepreneurial process. J. Bus. Ventur. 1985, 1, 107-117. [CrossRef]

23. Uzzi, B. Social Structure and Competition in Interfirm Networks: The Paradox of Embeddedness. Adm. Sci. Q. 1997, 42, 35. [CrossRef]

24. Zimmer, C.; Aldrich, E.H. Resource Mobilization through Ethnic Networks. Sociol. Perspect. 1987, 30, 422-445. [CrossRef]

25. Brand, M.J.; Croonen, E.P.M.; Leenders, R.T.A.J. Entrepreneurial networking: A blessing or a curse? Differential effects for low, medium and high performing franchisees. Small Bus. Econ. 2017, 50, 783-805. [CrossRef]

26. Jiang, X.; Liu, H.; Fey, C.; Jiang, F. Entrepreneurial orientation, network resource acquisition, and firm performance: A network approach. J. Bus. Res. 2018, 87, 46-57. [CrossRef]

27. Steier, L.; Greenwood, R. Entrepreneurship and the Evolution of Angel Financial Networks. Organ. Stud. 2000, $21,163-192$. [CrossRef]

28. Schutjens, V.; Stam, E. The Evolution and Nature of Young Firm Networks: A longitudinal Perspective. Small Bus. Econ. 2003, 21, 115-134. [CrossRef]

29. Greve, A.; Salaff, J.W. Social Networks and Entrepreneurship. Entrep. Theory Pr. 2003, 28, 1-22. [CrossRef]

30. Soetanto, D. Examining change in entrepreneurial networks: Using visualisation as an alternative approach. Eur. Manag. J. 2019, 37, 139-150. [CrossRef]

31. Stuart, T.E.; Hoang, H.; Hybels, R.C. Interorganizational Endorsements and the Performance of Entrepreneurial Ventures. Adm. Sci. Q. 1999, 44, 315. [CrossRef]

32. Jones, C.; Hesterly, W.S.; Borgatti, S.P. A General Theory of Network Governance: Exchange Conditions and Social Mechanisms. Acad. Manag. Rev. 1997, 22, 911. [CrossRef]

33. Granovetter, M.S. The Strength of Weak Ties. Am. J. Sociol. 1973, 78, 1360-1380. [CrossRef]

34. Ruef, M. Strong ties, weak ties and islands: Structural and cultural predictors of organizational innovation. Ind. Corp. Chang. 2002, 11, 427-449. [CrossRef]

35. Huggins, R.; Thompson, P. Entrepreneurial networks and open innovation: The role of strategic and embedded ties. Ind. Innov. 2017, 24, 403-435. [CrossRef]

36. Arregle, J.; Batjargal, B.; Hitt, M.A.; Webb, J.W.; Miller, T.; Tsui, A.S. Family Ties in Entrepreneurs' Social Networks and New Venture Growth. Entrep. Theory Pr. 2015, 39, 313-344. [CrossRef]

37. Van De Ven, A.H.; Poole, M.S. Explaining Development and Change in Organizations. Acad. Manag. Rev. 1995, 20, 510. [CrossRef]

38. Hite, J.M.; Hesterly, W.S. The evolution of firm networks: From emergence to early growth of the firm. Strat. Manag. J. 2001, 22, 275-286. [CrossRef]

39. Wahyuningtyas, S.Y.; Hanoteau, J.; Vial, V. The role of social networks in entrepreneurial ecosystems: The case of \#StartupLokal in Jakarta. Glob. Bus. Organ. Excel. 2018, 37, 22-29. [CrossRef]

40. Riar, F.J.; Bican, P.M.; Fischer, J. It wasn't me: Entrepreneurial failure attribution and learning from failure. Int. J. Entrep. Ventur. 2021, 13, 113-136. [CrossRef]

41. Hill, J.; McGowan, P.; Drummond, P. The development and application of a qualitative approach to researching the marketing networks of small firm entrepreneurs. Qual. Mark. Res. Int. J. 1999, 2, 71-81. [CrossRef]

42. Jack, S.L. Approaches to studying networks: Implications and outcomes. J. Bus. Ventur. 2010, 25, 120-137. [CrossRef]

43. Yin, R.K. Case Study research and Applications: Design and Methods, 6th ed.; SAGE Publications, Inc: Los Angeles, CA, USA, 2018.

44. Coviello, N.E. Integrating qualitative and quantitative techniques in network analysis. Qual. Mark. Res. Int. J. 2005, 8, 39-60. [CrossRef]

45. Mayring, P. Qualitative Inhaltsanalyse: Grundlagen und Techniken, 12th ed.; Beltz Verlag; Weinheim, Germany, 2015.

46. Koudstaal, M.; Sloof, R.; Van Praag, M. Risk, Uncertainty, and Entrepreneurship: Evidence from a Lab-in-the-Field Experiment. Manag. Sci. 2016, 62, 2897-2915. [CrossRef]

47. Bican, P.M.; Brem, A. Digital Business Model, Digital Transformation, Digital Entrepreneurship: Is There A Sustainable "Digital”? Sustainability 2020, 12, 5239. [CrossRef]

48. Kuckertz, A.; Brändle, L.; Gaudig, A.; Hinderer, S.; Reyes, C.A.M.; Prochotta, A.; Steinbrink, K.M.; Berger, E.S. Startups in times of crisis-A rapid response to the COVID-19 pandemic. J. Bus. Ventur. Insights 2020, 13, e00169. [CrossRef]

49. Hommel, K.; Bican, P. Digital Entrepreneurship in Finance: Fintechs and Funding Decision Criteria. Sustainability 2020, $12,8035$. [CrossRef]

50. Riar, F.J.; Hienerth, C.; Jensen, M.B. Digital due diligence activities and goal setting in equity crowdfund-ing: Exploring the differences between novice and experienced investors. Int. J. Entrep. Ventur. 2021, 13, 1-26.

51. Hohl, L.; Bican, P.M.; Guderian, C.C.; Riar, F.J. Gender Diversity Effects in Investment Decisions. J. Entrep. 2021, $30,134-152$. [CrossRef]

52. Guderian, C.C.; Bican, P.M.; Riar, F.J.; Chattopadhyay, S. Innovation management in crisis: Patent analytics as a response to the COVID-19 pandemic. RED Manag. J. 2021, 51, 223-239. 